\title{
Hijra - The Sex in Between
}

\author{
Anila Mithani and Fateh Muhammad Burfat \\ SZABIST \\ Karachi, Pakistan
}

\begin{abstract}
Nature has not been uniform in its creations, producing a spectrum of variances wherever possible. Some have wealth while others are poor, few have attractive physical features while others have ugly faces. Similarly there are variations in human sex resulting into possibilities that cannot be clearly partitioned into either of the sexes. It's this intermediate sex that is the subject of this study - the people known as Hijra or Chhakka. The other names labeled to them by the society are Khadra, Khusra, Zanana, Murat, K-2, third-sex, or third world.
\end{abstract}

The researcher has adopted a qualitative approach for the study and has conducted informal interviews with the respondents while referring to secondary data wherever required. The researcher contacted respondents belonging to various localities of Karachi, practicing various religions (Muslims, Christians). The researcher has avoided the use of the names of these respondents and refers to them simply as respondents.

The aim of the study is to understand the different aspects of the life of these people, from their perspective. They usually live as a community. The research has been carried out with the hope of letting the society understand their differences, lifestyle and the reasons behind their peculiar way of living.

\section{INTRODUCTION}

No specific definition is available for a Hijra. Hijras are categorized as neither male nor female, i.e. belonging to neither of the sexes. They dress up like women, wear jewellery and make-up, keep long hair like most women and like to be referred as 'she'. They have feminine names and live within their own separate community. They imitate the lifestyle and behaviour of women because that is what they want to be, and are not biologically women or have abnormal genitalia.

Their traditional occupation is performing dances and giving blessings at valued ceremonies and occasions. Some of them are intersexuals, some are impotent, some have done emasculation and some have not. Thus, there are varieties of Hijra, and one cannot give a single definition that covers all that they are.

It is worth mentioning here that Hijras, as we know them, are only found in the sub-continent. Sometimes 'hermaphrodite' is used as a synonym of Hijra, which is a wrong translation and so is 'eunuch'. These are kinds of Hijras but cannot be equated with the whole community.

\section{KINDS OF HIJRAS}

There are three kinds of Hijra in our society:

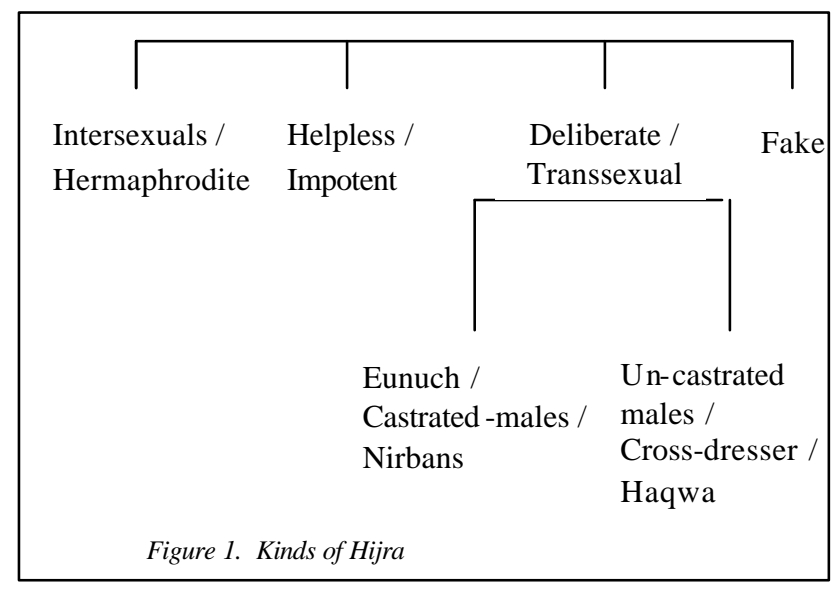

\section{Intersexuals/Hermaphrodite}

Hijras having ambiguous genitalia (external sexual organs) come under this category. Ambiguous genitalia result in difficulty in classification of an infant by physical examination as a male or a female.

Hermaphrodite is a person or an animal that has both male and female sexual organs or characteristics. They are of three types:

True hermaphrodite: A person born with both ovary (female sexual organ) and testicular tissue (male sexual organ).

Female pseudo: A person born XX with normal female internal organs but with "masculanized" genitalia (Internal female sexual organs but physically looks as a male because of having external male sexual organ).

Male Pseudo: A person born XY with testes. The external genitalia are usually of female (opposite of female pseudo). [1]

Some babies may have ambiguous genitalia due to hormonal imbalances. The basic pathology is either lack of or overproduction of hormones or some genetic anomaly.

According to Dr. Iftikhar Ahmed Jan, it is very easy to manipulate the hormonal influence and convert such new born babies having ambiguous genitalia to their normal sex or the sex that will provide the best and normal functional 
life to a child. According to him, it is just an ailment like diabetes and it is correctable in most cases. [2]

According to one of the respondents of Dalrymple, when she was born, a midwife told her mother that the child is neither male nor female and that baby is a Hijra. This news spread like wildfire. Her mother fearing the consequences left the village with the baby. On the following day her mother died, and the baby was brought back to their village and was handed over to one of the guru, as the baby was a Hijra. The person still lives with this guru. [3]

\section{Helpless/Impotent}

Those males who are impotents (incapable of sexual intercourse) are helpless in our society. They are labeled as incomplete man or neither man nor woman and thus are expelled from social arcles. As Nanda noted, in South Asia "being independent of the group means not freedom, but social suicide" [4]. So, when their families and society exclude them than an alternative support system is crucial for their survival and to avail this, they are welcomed by the Hijra community.

One of the respondent was engaged and just before his marriage his doctor told him that he doesn't have a functional genital and he broke up with his fiancé. He had no other choice but to become a Hijra. According to him, "No one from her own wishes joins this community. It is because of non-functioning sexual organs and the desire to be a woman."

\section{Deliberate/Transsexuals :}

There are Hijras, who are born as normal males but have a desire to change their sex. They leave their original identity and join the Hijra community. In other words, males who are transsexuals, also join the Hijra community.

The World Health Organization (WHO) defines Transsexuals as, "Those who have a desire to live and be accepted as a member of the opposite sex, usually accompanied by a sense of discomfort with, or inappropriateness of, one's anatomical sex, and a wish to have surgery and hormonal treatment to make one's body as congruent as possible with one's preferred sex."

Within transsexuals, there are two variants:

\section{Eunuchs/castrated-males/Nirbans:}

Males with removed genitalia by a crude operation (termed as castration/emasculation) for the desire to be of opposite sex.

\section{Un-castrated-males/cross-dresser/Haqwa:}

Transsexuals, who have joined Hijra community but have not undergone castration.

\section{Fake Hijras}

These are perfect male who wear or dress as women to beg on streets and pretend as Hijras.

\section{LIFE STYLE}

Hijras live in groups of ten to fifteen members per locality. They refer to each other as "she" because they think of themselves as women. Everything a woman can do, they can do too, except bear children. They live in rented houses and usually share it among three to five members. Major portion of their earnings are spent on outfits, jewellery and make-up. Each of their costumes, for functions, cost around Rs.3,000-5000.

They wish to look more beautiful, attractive and outstanding than others. Therefore to attend any function or for performing in functions or in their own celebrations, they spend a lot of money in showing themselves off. One of the reasons for intense jealousy among them is the competition as to 'who is more beautiful' or who is more admired in functions or who earns more money because of her good looks, style, etc. They usually travel in rickshaw. The reason for avoiding buses is that they are not allowed to sit in the ladies compartment and in the male compartment they are being teased and touched by men. Some of them use injections or cream to develop breasts. Otherwise hey use cotton and other stuff in place of breasts to resemble the female figure.

\section{COMMUNITY STRUCTURE}

They call each other 'sister', 'daughter', 'aunt' or 'mother-in-law'. The Hijra hierarchy revolves round four echelons: chela, guru, maha guru and jama or panchayat. [5]

\section{Chela/ Shagird}

Chela is a hindu word that means a 'disciple' or a follower. They organize functions, when a guru (leader of a group of Hijras) accepts a new Chela. In this ceremony all of them get together in party dresses and then the Guru pricks a bali in her Chela's nose (nakh chaidana). The new Chela dresses up like a bride. The whole function resembles a typical subcontinental wedding, in which mayuun (bride wearing yellow dress) and all other ceremonies take place. Afterwards, each one of them (friends, guru, mummy) give gifts to the new Chela (called Badahi)

\section{Guru}

The relationship between a Guru and a Chela is like that of a mother and a daughter in which the elements of obedience and loyalty are predominant. They do not necessarily live with gurus. Some of them live alone.

\section{Maha-Guru / Nayak}

$\mathrm{He}$ is either selected by the panchayat or is chosen by the former Maha-Guru. A Maha-Guru is highly respected person in the community. He is supposed to perform hajj. After hajj, he wears white dress only [5]. 


\section{Punchayat}

Usually Hijras use traditional means of social control. Senior members or Gurus of their community called a punchayat, takes the necessary decisions. Punchayats also ensure that all the Hijras stick on the code of conduct set by them. They can fine (dund) or expel one from the community. When a chela changes a guru, her new Guru has to pay twice the price to the previous guru that the previous guru had paid for or spent on her.

\section{SOURCES OF INCOME}

Their sources of earning include begging, dancing at carnivals, weddings and births and in some cases, prostitution.

\section{By paying visits}

Hijras especially pay visit to families of newly born children/newly wed where they are paid to give blessings or due to the fear of curse, to get rid of them. The territories are distributed by their guru. Their routine is to go daily or whenever they hear such news of birth of a baby or a marriage ceremony and demand money from those having the celebration. They come to know about the events from neighbors of the newly wed/newly born or use hints from other symbols, like decorations, celebrations, hanging baby clothes, etc.

\section{Dancing}

They are frequently invited at functions and marriage ceremonies to perform dances, mostly on weekends. They get paid by the host and earn additional cash from the spectators (tamashbeen). They prepare for the function in a very exclusive manner (expensive dresses and make-up) and go to the event as a group. To win spectator's and to attract money, they use various tactics and sexual appeal.

\section{Begging}

Some Hijras beg on the streets and/or visit shops in their territory for the purpose.

\section{Prostitution}

Another source of earning is by blackmailing or prostituting at night. Some people also offer them to stay after functions or invite them to live for a day or even a month with them and offer cash payment as well as jewellery for the same. They consider prostitution as a sin and normally don't prefer to admit that they are engaged in such an act but most of them are engaged in it. According to one subject: "There so no difference between our life and Tawaif, people play with our body and so does with their's."

Sometimes people kidnap them and force them to fulfill their sexual desires. People tease them differently like "Kahan ja rahi ho, hamare sath chalo (where are you heading? Why don't you join me)" or try to touch them at various parts of the body.

\section{CASTRATION/EMASCULATION}

As some Hijras are transsexuals, they are not happy with their physical sexual organs and want to look like women. To fulfill this desire they go through a very crude surgical operation known as castration. In this, the male genitals (penis and testicle) are removed to make them look like a woman. Advantages of castration include appearance of sexual organs like women and decrease in the growth of body hair (including facial hair). Castration increases their respect, and the demand rises too. This operation is done by any member of the community or by the doctor, on payment of a handsome amount, usually around Rs.12,000/-. Of those in Karachi, most have undrgone castration from Punjab. The procedure for carrying out this risky operation according to one respondent is as follows:

"First by injections the area around the genital is made insensitive/numb, then the organ is tied with a rope and the subject is asked to look on roof and is distracted to talks. Then, with a knife or with a sharp big blade, the organ is cut-off. After this cut intense bleeding follows. Then bandages are applied, antibiotics are given and polyfax ointment is applied. It takes $2-3$ months to fully recover from the pain. Meanwhile the guru or some other friends take care of her. In some cases when police came to know about the operation, they take money from them for not disclosing about this operation."

\section{MARRIAGES AND RELATIONS WITH GIRYA}

Hijras don't have marriages but are involved into a relationship similar to that between a husband and a wife, with a man called Girya. Girya is not from the Hijra community, but is a normal male who is involved in a sexual relationship with a Hijra; sometimes the Giryas have their own family and children. This is the reason for Hijras being commonly known as homosexuals. Every Hijra has a Girya (male friend), with whom they make love and share their feelings. Some Giryas visit them almost daily, while others occasionally. The Hijra have sexual relations with the Girya in which they play a submissive role. They are committed to one Girya at a time, and are loyal and devoted to him. They would not get involved in sexual relationships (except as a source of income) with any other man during their relationship with a Girya. After a Girya leaves, another one is selected who matches the likes and wishes of the Hijra. Their relationship with each other is like a husband and wife. They also have fights and sometimes Giryas physically assault them over issues like possessiveness. Giryas also give cash and gifts to them, including gold, jewellery and dresses.

\section{EARLY LIFE AND REASONS FOR JOINNG THE HIJRA COMMUNITY}

Most of them are transsexuals and they have this tendency or wish to be a woman from early childhood. Before joining this community, they usually spend most of 
their time among female colleagues in schools, etc. Despite having male names they act, walk and talk like girls and also wear kajal/surma and nail polish to look like girls. All the respondents had similar comments about their specific behavior: "God has given us a woman soul, we are not aroused when we see a lady but we $b$, when we see a handsome man. All women are our sisters".

In City of Djinns - A year in Delhi, William Dalrymple came across eunuchs and he had lots of discussions with them. In the same context, he says, "The vast majority of eunuchs, and almost all those I met, were born physically male. In Europe they would probably describe themselves as transsexuals and have a full sex change. But in India the technology for this does not exist. The only choice is between brutal and extremely dangerous - village castration, or for those who can afford it, a course in hormone pills followed by an anaesthetized operation. The operation is illegal in India, but there are several doctors who, for a fee, are willing to take the risk." [3]

Another very dreadful fact and the reason behind joining a Hijra community is their early life sexual experiences. Some of these people had sexual relationships (had anal sex) with other men (of the same or older age) starting from their childhood, at the age of around 12 to 18 years (during school life, either voluntarily or nonvoluntarily). During love making, the respondents played a submissive role. These initial male partners were often their school colleagues or some elder friend living in their mohalla. With time, this became a habit as well as a source of pleasure during that critical age (teenage) of development and growth. They made this exercise a habit, practicing with different colleagues, playing the same role. They never exchange roles nor have had any sexual relationship with females. In other words, they have never behaved as men during sexual relationships. When they grow up, they find the easiest way out for fulfilling their desires as a homosexual is by joining this community. They form a small group in their mohallah and are quite popular due to their particular lifestyle. Therefore as and when these young boys (as transsexuals or homosexuals) grow up and find (from Hijras and friends) that their behavior and desires are similar to the Hijra community, they prefer to join them as a member, as a means to fulfill their wishes and to get the freedom to enjoy the particular, variant lifestyle. All of them, regardless of their families' reluctance join this community and change their names to a feminine one and started living like them.

All of them have only one wish, "To become a woman". About their way of earning, some want to change, but according to them no one would give them any opportunity to do an honorable work, as they are still not accepted as humans. Others don't want to leave their style of earning which gives them complete freedom (no schedule, no restrictions on sleeping). To them job would be a prison, they don't want to leave their present luxurious life style, which is available as a part of this community.
Some Hijra have not done castration and the reason behind is, "If at some moment in later their life, we decide to come back to our normal life, we would like to live like a male as it would be easy, otherwise if we undergo castration it would not be possible to return to normal".

\section{CONCLUSION}

Awareness should be created in parents that their active role in the development and socialization of their children plays an important role in bringing up a normal child. Parents should take notice of feminine acts in their boys immediately and should talk and discuss with them, and if any gender confusion is found or observed, they should immediately have their counseling with experts or with concerned psychologists. They should avoid making fun of their particular behavior or to encourage the same that may eventually lead to the joining of this community.

The social environment also plays a major role. It was observed with all the respondents that their friends and colleagues exposed them to sexual experiences. This led to their involvement at a very early age (due to their innocence) in homosexuality. With the passage of time, this act became a habit as well as a source of pleasure. Lack of sex education plays a major role in such cases and the related issues. Proper knowledge and awareness related to this aspect should be shared with young children making them aware of the benefits and drawbacks, otherwise the media or other resources could misguide them and may lead them to a wrong direction.

Similarly when respondents found that they didn't have a functional male organ and are not capable as a male, the surroundings and society labeled them as Hijra and forced them to join Hijras because they did not belong to the general society. This incorrect attitude of the society needs to be changed. It is for sure that for whatever reasons they are being outcaste by the society; this should not be encouraged in the future. As we now understand that some are intersexuals, who, if diagnosed at the right age, can be cured. Those who have non-functional genitals should not be labeled by the society as an incomplete men or a Hijra.

For transsexuals, a proper counseling platform needs to be created and they should not be separated from the rest of the society. Instead of forcing them to form their own isolated community, quite different from the rest and without much moral or social assistance, we should support and help them to gain their rights and place in the society without any discrimination based on their lifestyle or gender identity. We should try to accept them for what they are and make sure that their respect and dignity is not sacrificed when such contacts are established.

\section{REFERENCES}

[1] Parker A. Leslie, "Ambiguous Genitalia: Etiology, Treatment, and Nursing Implications", JOGNN Principles \& Practice Volume 27,15-22, Jan/Feb 1998. 
[2] Iftikhar Ahmed Jan, an article on The third sex: myth or reality, Sunday Dawn magazine, February 3, 2002.

[3] Dalrymple William, "City of Djinns - A Year in Delhi", Flamingo An imprint of Harper Collins Publishers, pp. 169-183.

[4] Nanda, Serena, Neither Man nor women, The Hijras of India, Wads Worth Publishing Company, Belmont California, 1990.

[5] Junejo, Tanvir, "Eunuchs - The cultural heritage of Sindh", Sindh University. Res. Journal (Arts Ser.) Vol. XXIX. 32-46, 1994. 